\title{
Investigating the within-herd prevalence and risk factors for ketosis in dairy cattle in Ontario as diagnosed by the test-day concentration of $\beta$-hydroxybutyrate in milk
}

\author{
Elise H. Tatone, ${ }^{*}$ Todd F. Duffield, ${ }^{* 1}$ Stephen J. LeBlanc, ${ }^{*}$ Trevor J. DeVries, $†$ and Jessica L. Gordon* \\ ${ }^{*}$ Department of Population Medicine, and \\ †Department of Animal Biosciences, University of Guelph, Guelph, ON, Canada, N1G 2W1
}

\begin{abstract}
An observational study of 790 to over 3,000 herds was conducted to estimate the within-herd prevalence and cow-level risk factors for ketosis in dairy cattle in herds that participate in a Dairy Herd Improvement Association (DHIA) program. Ketosis or hyperketolactia (KET) was diagnosed as milk $\beta$-hydroxybutyrate $\geq 0.15 \mathrm{mmol} / \mathrm{L}$ at first DHIA test when tested within the first $30 \mathrm{~d}$ in milk. Seven hundred ninety-five herds providing at least 61 first milk tests from June 2014 to December 2015 were used to estimate the provincial within-herd prevalence of KET. All herds on DHIA in Ontario $(\mathrm{n}=3,042)$ were used to construct cowlevel multilevel logistic regression models to investigate the association of DHIA collected variables with the odds of KET at first DHIA milk test. Primiparous and multiparous animals were modeled independently. The cow-level KET prevalence in Ontario was 21\%, with an average within-herd prevalence of $21 \%$ (standard deviation $=10.6$ ) for dairy herds enrolled in a DHIA program. The prevalence of KET had a distinct seasonality with the lowest prevalence occurring from July to November. Automatic milking systems (AMS) were associated with increased within-herd prevalence, as well as increased odds of KET in multiparous animals at first test (odds ratio: 1.45; 95\% confidence interval: 1.30 to 1.63 ). Jersey cattle had over 1.46 times higher odds of KET than Holstein cattle. Milk fat yield $\geq 1.12$ $\mathrm{kg} / \mathrm{d}$ at the last test of the previous lactation was associated with decreased odds of KET in the current lactation (odds ratio: $0.56 ; 95 \%$ confidence interval: 0.53 to 0.59$)$. Increased days dry and longer calving intervals, for multiparous animals, and older age at first calving for primiparous animals increased the odds of KET at first test. This study confirms previous findings that increased days dry, longer calving intervals, and
\end{abstract}

Received May 12, 2016.

Accepted September 17, 2016.

${ }^{1}$ Corresponding author: tduffiel@uoguelph.ca increased age at first calving are associated with increased odds of KET and is the first report of increased KET in herds with AMS and in relation to milk fat yield at the final test of the previous lactation. Feeding management on AMS herds likely contributes to the increased prevalence of KET and further work is required to investigate modifications to current management to minimize risk. Milk fat yield during the previous lactation may be representative of energy partitioning.

Key words: ketosis, beta-hydroxybutyrate, dairy cattle

\section{INTRODUCTION}

Ketosis (KET), blood BHB $\geq 1.2 \mathrm{mmol} / \mathrm{L}$, is a costly disease for the dairy industry (McArt et al., 2015). Ketosis prevention and disease management require knowledge of within-herd prevalence and management factors that contribute to the risk of disease. Several cross-sectional prevalence studies of KET have been conducted in Europe (Suthar et al., 2013; Berge and Vertenten, 2014; Vanholder et al., 2015), in grazing herds in New Zealand (Compton et al., 2014) and Argentina (Garro et al., 2014), in Iran (Asl et al., 2011), and in Jordon (Al-Rawashdeh, 1999). Recent North American KET prevalence and incidence estimates are based on few herds, often convenience samples, obtained during clinical trials of treatment of KET (McArt et al., 2012; Gordon, 2013). A study of 92 convenience-sampled dairy herds across Ontario, Canada, was completed in 1992 (Duffield et al., 1997); however, the herds at the time were mostly component-fed, tiestall herds. The landscape of the dairy industry in Ontario has changed in the last $24 \mathrm{yr}$ to include over $26 \%$ freestall herds and $7 \%$ herds with automated milking systems (AMS; Canadian Dairy Commission, 2015). The DHIA (CanWest DHI, Guelph, ON, Canada) introduced the Ketoscreen milk BHB test (MilkoScan FT600, Foss Analytical A/S, Hillerød, Denmark) in June 2014. The optimal threshold based on association with clinically relevant outcomes has not been established; however, the KET 
or hyperketolactia threshold in use by DHIA was milk BHB $\geq 0.15 \mathrm{mmol} / \mathrm{L}$ based on the optimal FTIR threshold to predict milk $\mathrm{BHB} \geq 0.10 \mathrm{mmol} / \mathrm{L}$ using a continuous flow analyzer (San ++ , Skalar, Breda, the Netherlands; Foss Analytical, 2009). The coefficient of variation for repeatability of the FTIR milk BHB test is $4.56 \%$ (D. Santschi, Valacta, Ste-Anne-de-Bellevue, Quebec Canada, personal communication). Test-day BHB and milk production measurements were available for $80 \%$ of all herds across the province. The province of Ontario accounts for one-third of the dairy herds in Canada. The herds on DHIA encompass a range in herd sizes, breeds, barn types, and milking systems, which provide an opportunity to explore the association of these variables on herd-level and cow-level KET prevalence.

Over-conditioned cows, BCS $\geq 3.5$, or above the median for BCS at calving, are associated with an increased risk of KET in early lactation (Gillund et al., 2001; McArt et al., 2015). Recording BCS routinely pre-calving can be used to identify animals at a higher risk for KET in the next lactation. Not only is BCS measurement subjective, but it also requires consistent recording to be useful, which has not been adopted in many herds. It has been suggested that milk fat production in late lactation could be a surrogate measure for conditioning (Baldwin et al., 1985; Allen and Piantoni, 2014). Cattle that partition fat into milk may be less likely to deposit fat in body stores. It may be possible to use measures other than BCS in late lactation, such as milk fat percentage, to identify cows at risk for KET in the next lactation. Different variables and risk factors were relevant for primiparous (PP) compared with multiparous (MTP) cows. Prepartum management factors of interest for MTP cows included dry period length and calving interval, whereas age at first calving was of interest for PP animals. Multiparous cows also had milk production data from previous lactations that could be included as possible risk factors for KET in the current lactation.

The objectives of this work were to (1) define a milk BHB threshold for use with the DHIA milk BHB test based on the effect on first test milk production, (2) estimate the population level and within-herd prevalence of KET for dairy herds in Ontario, (3) investigate herdlevel variables associated with the within-herd KET prevalence, and (4) investigate herd-level and cow-level variables associated with having KET for PP and MTP cows independently.

\section{MATERIALS AND METHODS}

A data set of test-day information from all Ontario herds enrolled in a DHIA program (Canwest DHI,
Guelph, ON, Canada) from June 2014 to December 2015 was compiled. Variables were extracted from the larger DHIA database stored in Oracle version 9i (Oracle Corporation, Redwood Shores, CA) and copied into Excel (Excel for Mac version 15.5.4, Microsoft, Redmond, WA) spreadsheets before being imported into SAS (SAS 9.3, SAS Institute Inc., Cary, NC) for data manipulation and analysis. Variables of interest included cow-level test-day data related to milk production, milk components, and BHB, as well as herd-level data describing herd size, barn type, and milking system. The BHB was measured in mmol/L (Ketoscreen test, MilkoScan FT600, Foss Analytical A/S, Hillerød, Denmark) at first DHIA test when the first test occurred before 30 DIM. Milk samples were collected through routine DHIA testing, preserved with bronopol tablets (Brotab, Systems Plus, Baden, ON, Canada), and transported to the CanWest DHI laboratory in Guelph, ON. The number of KET positive tests before 30 DIM were compared with all tests performed within the same timeframe to determine the KET prevalence on Ontario dairy herds enrolled in a DHIA program. Subgroups were formed to explore the variation in prevalence by variables of interest (Table 1 ). The most recent test was retained if animals had multiple first tests over the 19-mo test period to avoid violating the model assumption of independence. Samples that were recorded as abnormal by the DHIA laboratory were excluded from analysis.

\section{Statistical Analysis}

For all KET prevalence models, univariable associations were offered to the multivariable models if $P \leq 0.05$. All variables with a significant univariable association with the outcome were examined for collinearity. A single variable was selected based on biological plausibility if 2 variables had correlation $\geq 0.6$ on Spearman rank (categorical) or Pearson (continuous) correlation coefficients. Quadratic terms were examined for all continuous predictor variables and retained if significant to fulfill the assumption of linearity. The final multivariable models were constructed using backward stepwise elimination. Variables were retained in the multivariable model if $P<0.01$ or if removal of the variable changed other variables' estimates by $20 \%$ or more, indicating evidence of confounding. The amount of unexplained variation at the herd level, the intra-class correlation coefficient (ICC), was calculated using a latent-variable approach (Dohoo et al., 2009).

Milk BHB Threshold. To establish a threshold for KET based on the DHIA milk BHB test, multilevel linear regression models were constructed using first test milk yield $(\mathrm{kg} / \mathrm{d})$ as the outcome of interest and 
Table 1. Variables included in examination of risk factors for within-herd prevalence of ketosis (milk BHB $\geq 0.15$ mmol/L) at first DHIA milk test for dairy herds in Ontario, Canada, on a DHIA program ${ }^{1}$

\begin{tabular}{|c|c|}
\hline Variable & Description \\
\hline \multirow[t]{2}{*}{ Barn type $e^{2,3,4}$} & Freestall (referent) \\
\hline & Tiestall \\
\hline Automatic milking system ${ }^{2,3,4}$ & No (referent) \\
\hline Predominant breed $^{4}$ ( $>50 \%$ of cows in the herd) & $\begin{array}{l}\text { Jersey } \\
\text { Other }\end{array}$ \\
\hline \multirow{3}{*}{ Animal breed ${ }^{2,3,5}$} & Holstein (referent) \\
\hline & Jersey \\
\hline & Other \\
\hline \multirow[t]{3}{*}{ Parity $^{3,5}$} & Parity $=1$ \\
\hline & Parity $=2$ (referent) \\
\hline & Parity $\geq 3$ \\
\hline \multirow{2}{*}{ Season of test ${ }^{5}$} & Spring (referent) \\
\hline & Summer \\
\hline Seasonal distribution ${ }^{4}$ & $\begin{array}{l}\text { Autumn } \\
\text { Proportion of tests occurring in each season (categorized): }\end{array}$ \\
\hline Seasonal distribution & $\begin{array}{l}\text { Proportion of tests occurring in each season (categorized): } \\
<33 \% \\
\geq 33 \%\end{array}$ \\
\hline Test year ${ }^{2,3}$ & 2014 or 2015 \\
\hline Month of first test ${ }^{2,3}$ & Categorized by month (referent $=$ May) \\
\hline Mean DIM at first test ${ }^{4}$ & DIM at first test averaged across the herd \\
\hline DIM at first test ${ }^{2,3,5}$ & $\begin{array}{l}\text { Categorized: } \\
<14 \text { DIM } \\
14 \text { to } 21 \text { DIM } \\
>21 \text { DIM (referent) }\end{array}$ \\
\hline Calving age $^{2}$ & $\begin{array}{l}\text { Categorized by the median for parity }=1 \text { : } \\
18 \text { to } 25 \mathrm{mo} \text { (referent) } \\
25 \text { to } 33 \mathrm{mo}\end{array}$ \\
\hline Herd average $\mathrm{M} 305^{2,3,4}$ & $\begin{array}{l}\text { Categorized by quartile: } \\
<8,113 \mathrm{~kg} \text { (referent) } \\
8,113 \text { to } 8,908 \mathrm{~kg} \\
8,908 \text { to } 9,573 \mathrm{~kg} \\
>9,573 \mathrm{~kg}\end{array}$ \\
\hline Previous milk yield ${ }^{3}$ & $\begin{array}{l}\text { Total milk yield }(\mathrm{kg}) \text { of the previous lactation for parity } \geq 2 \text { categorized by quartile: } \\
>8,660 \mathrm{~kg} \text { (referent) } \\
8,660 \text { to } 10,386 \mathrm{~kg} \\
10,386 \text { to } 12,301 \mathrm{~kg} \\
>12,301 \mathrm{~kg}\end{array}$ \\
\hline Fat yield at last test ${ }^{3}$ & $\begin{array}{l}\text { Milk fat yield at the final DHIA test of the previous lactation: } \\
\geq 0.70 \mathrm{~kg} \\
0.70 \text { to } 0.92 \mathrm{~kg} \\
0.92 \text { to } 1.12 \mathrm{~kg} \\
\geq 1.12 \mathrm{~kg}\end{array}$ \\
\hline
\end{tabular}

${ }^{1}$ Prevalence was modeled separately for parity 1 and parity $\geq 2$.

${ }^{2}$ Included in the ketosis (KET) at first test for parity $=1$ univariable analysis and multilevel logistic regression model; M305 is the 305 -d milk yield.

${ }^{3}$ Included in the KET at first test for parity $\geq 2$ univariable analysis and multilevel logistic regression model.

${ }^{4}$ Included in within-herd KET prevalence univariable analysis and multilevel linear regression model.

${ }^{5}$ Included in milk BHB threshold models. 
with different thresholds of milk BHB at first test as dichotomous explanatory variables of interest, similar to Duffield et al. (2009). The thresholds of milk BHB evaluated were $\geq 0.08,0.10,0.12,0.15,0.18,0.20,0.22$, 0.25 , and $0.28 \mathrm{mmol} / \mathrm{L}$ based on the commonly recommended cut points $\geq 0.1$ and $\geq 0.2 \mathrm{mmol} / \mathrm{L}$ milk $\mathrm{BHB}$ using semiquantitative milk strips (Geishauser et al., 2000; Samiei et al., 2010). The potential confounding effect of DIM at first test, season of test, parity, and breed were evaluated. Herd was included as a random effect. The lowest threshold with a negative estimate for milk yield and a $P \leq 0.05$ was chosen as the threshold for KET.

Within-Herd Prevalence. A linear regression model was constructed to explore factors associated with within-herd KET prevalence, including herds with $\geq 61$ tests over the sampling period $(\mathrm{n}=791)$. The required number of tests was determined using a proportion estimation sample size calculation assuming a within-herd prevalence of 20\% (Duffield et al., 1997), with $95 \%$ confidence, $80 \%$ power, and a precision of $10 \%$ around the estimate. To investigate the association of herd-level factors with the within-herd KET prevalence, within-herd KET prevalence was modeled as the outcome, using PROC GLM. Residuals were examined for normality and the assumption of homoscedasticity. Homoscedasticity was confirmed with the Cook-Weisberg test. To satisfy the assumption of normality, the outcome of within-herd KET prevalence was transformed by taking the square root.

Risk Factors for Ketosis in Primiparous and Multiparous Animals. All herds were included in the cow-level models $(\mathrm{n}=3,042)$. Two multilevel logistic regression models were constructed to determine factors associated with having KET at first DHIA test for PP $(\mathrm{n}=58,584)$ and MTP animals $(\mathrm{n}=108,196)$ independently, with herd included as a random effect. Primiparous animals were excluded if age at first calving was $<550$ or $>1,000 \mathrm{~d}$ to avoid including animals with incorrect calving age or incorrectly classified as PP. Multiparous animals were excluded if last test fat percentage $<1.5$, previous lactation yield $<2,000 \mathrm{~kg}$, days dry $>365 \mathrm{~d}$, or calving interval $<330 \mathrm{~d}$ to exclude those with unrepresentative or erroneous values.

\section{RESULTS}

\section{Milk BHB Threshold}

The lowest milk BHB threshold that was associated with decreased milk production at first test day was $\mathrm{BHB} \geq 0.15 \mathrm{mmol} / \mathrm{L}$. After controlling for parity, breed, season, and DIM at first test, having milk BHB $\geq 0.15 \mathrm{mmol} / \mathrm{L}$ was associated with $1.0 \mathrm{~kg} / \mathrm{d}$ lower milk production $(P \leq 0.001)$. The threshold associated with lower production is equivalent to the threshold currently employed by DHIA for KET diagnosis.

\section{Descriptive}

The overall prevalence of KET in Ontario based on 165,749 observations was $21 \%$. The prevalence was the highest [27\%; 95\% CI: 26 to 28\%] for cattle tested on 6 and 7 DIM. Prevalence decreased with increasing DIM, to $16 \%$ for cattle tested at 27 and 30 DIM (Figure 1a). Separating the prevalence of KET by PP and MTP illustrated a parity effect (Figure 1b). The prevalence of KET for PP animals was highest for those tested at 5 DIM and the prevalence followed a steady decline. The peak prevalence of KET for MTP animals was at 11 and 12 DIM. Prevalence also varied by season (Figure 2); summer (20\%; 95\% CI: 19.6 to 20.3) and autumn (18\%; 95\% CI: 17.3 to 17.9$)$ had lower KET prevalence compared with winter $(26 \%$; $95 \%$ CI: 25.5 to 26.5$)$ and spring $(25 \%$; $95 \%$ CI: 24.5 to 25.4$)$.

The average within-herd KET prevalence in dairy herds in Ontario was 21\% ( $\mathrm{SD}=10.7$; Figure 3) based on each herd's average prevalence between June 2014 and December 2015. Within-herd KET prevalence ranged from 0 to $59 \%$. A subset of herds (795) was used for the within-herd prevalence estimate. To be included in the within-herd prevalence estimate, herds were required to have a minimum of 61 animals with a DHIA test occurring within the first 30 DIM. Twentysix percent of the herds included in the main database had $>61$ animal tests. For those included in the withinherd prevalence estimate, the number of first tests per herd over the 19-mo period ranged from 61 to 710 , with a mean of $113(\mathrm{SD}=76)$. The herd demographics between the main data set and the within-herd prevalence subset differed. The average lactating herd size for those included in the within-herd KET prevalence estimate (795 herds) was 126 cows $(\mathrm{SD}=99$; range 39 to 1,184$)$ compared with 68 cows $(\mathrm{SD}=62$; range 4 to 1,184 ) for all herds in the complete database. The full data set had a higher proportion of tie-stall herds $(62 \%)$ compared with the herds included in the within-herd prevalence estimation (30\%; Table 2). The proportion of freestall herds was lower in the complete data set $(28 \%)$ than in the within-herd prevalence data set $(60 \%)$. In both the full data set and the subset with 61 tests or more, the majority of the milk BHB tests (>93\%) came from Holstein cows, with the remainder from Jersey, Guernsey, Ayrshire, Brown Swiss, Milking Shorthorn, and other cattle (Table 2). 


\section{Within-Herd Prevalence}

In univariable analysis, barn type $(P=0.03)$, having AMS $(P<0.001)$, having more than $33 \%$ of tests during the summer $(P<0.001)$, proportion of first-parity animals $(P=0.002)$, and average herd 305 -d milk yield (M305; $P=0.01)$ were associated with the transformed within-herd KET prevalence. Predominant breed $(P=$ $0.11)$, herd size $(P=0.46)$, average DIM at first test $(P=0.57)$, and average herd parity $(P=0.59)$ were

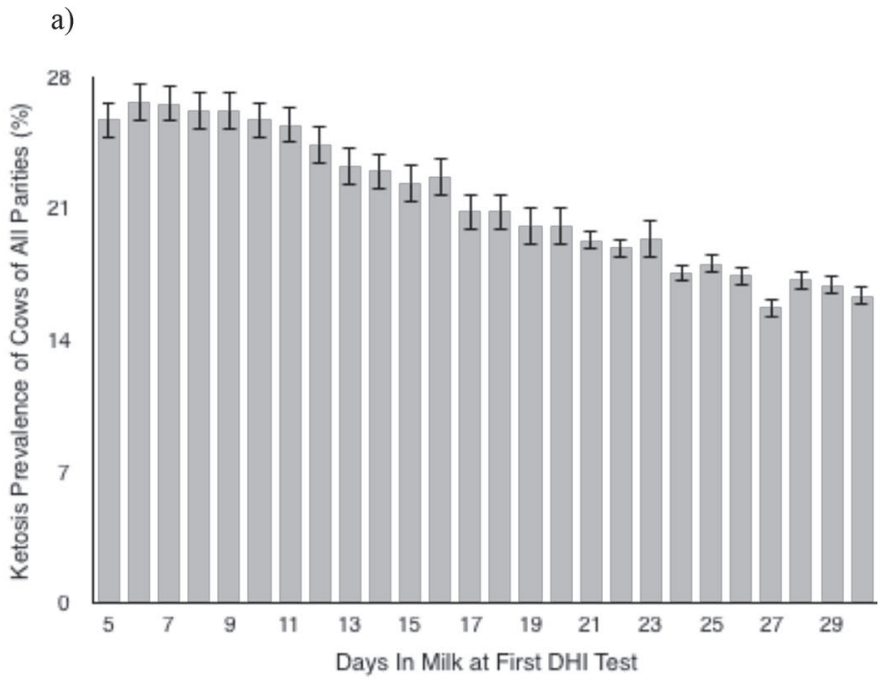

b)

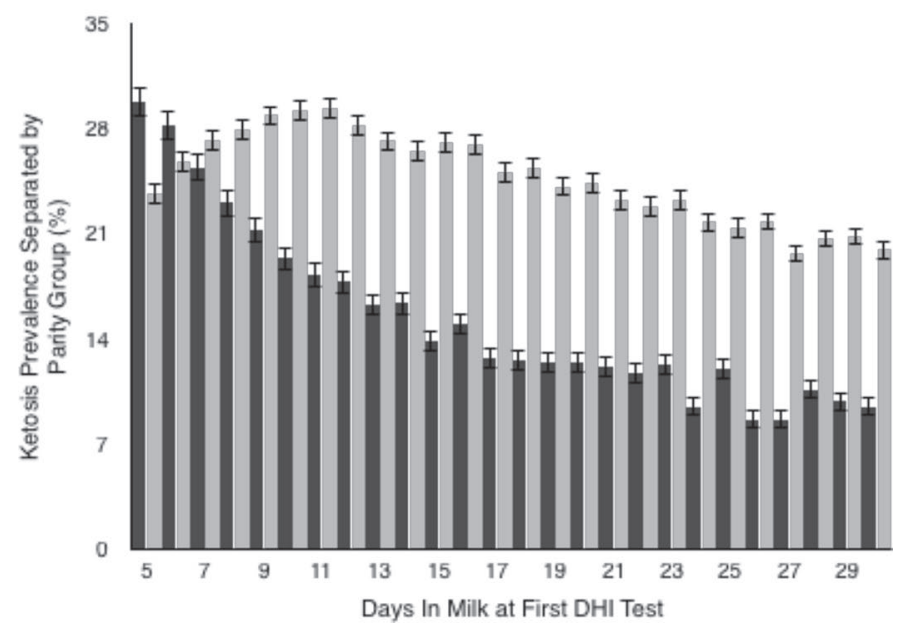

Figure 1. (a) Prevalence ( $\pm \mathrm{SE})$ of cow-level ketosis in the first 30 $\mathrm{d}$ of lactation by DIM at diagnosis, for 165,749 cows of all parities in 3,042 dairy herds enrolled in a DHIA program in Ontario, Canada. Ketosis was diagnosed by milk BHB $\geq 0.15 \mathrm{mmol} / \mathrm{L}$ at DHIA test. (b) Cow-level prevalence $( \pm \mathrm{SE})$ of ketosis in the first $30 \mathrm{~d}$ of lactation by DIM at diagnosis separated into primiparous $(\mathrm{n}=55,678)$ and multiparous $(\mathrm{n}=100,509)$ animals from 3,042 dairy herds enrolled in a DHIA program in Ontario, Canada. Ketosis was diagnosed by milk BHB $\geq 0.15 \mathrm{mmol} / \mathrm{L}$ at DHIA test.

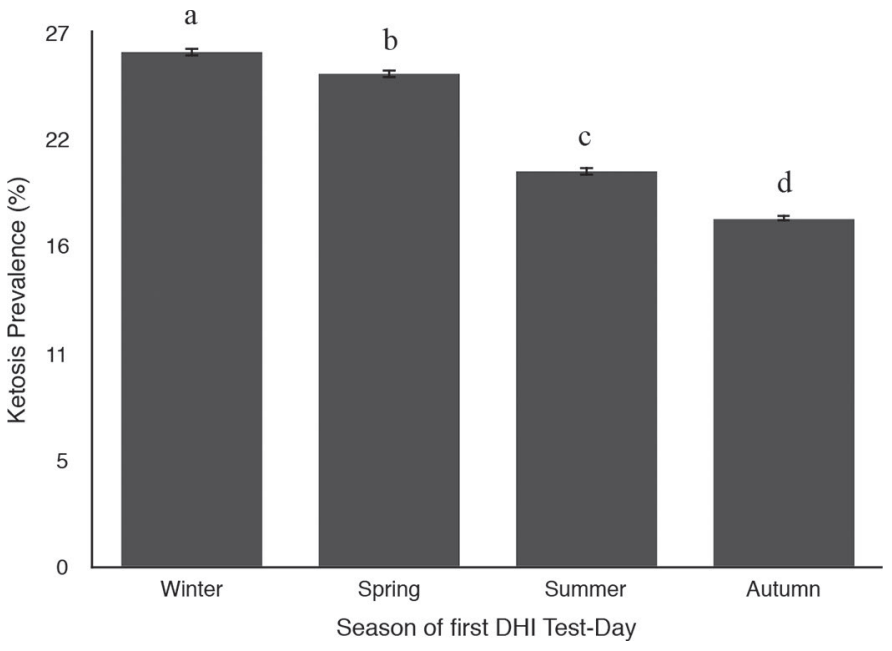

Figure 2. Seasonal variation of cow-level ketosis $( \pm \mathrm{SE})$ in the first $30 \mathrm{~d}$ of lactation based on season of first DHIA test for 165.749 cows in 3,042 dairy herds enrolled in a DHIA program in Ontario, Canada. Ketosis was diagnosed by milk BHB $>0.15 \mathrm{mmol} / \mathrm{L}$ at DHIA test. Letters a-d denote difference $(P<0.001)$ between seasonal prevalence.

not associated with the within-herd prevalence. Two variables were retained in the multivariable linear regression model: having AMS $(P<0.001)$ and having more than $33 \%$ of first tests in the summer $(P<0.001)$. Herds with more tests occurring in the summer were estimated to have a $2 \%$ lower within-herd KET prevalence. Herds with AMS were estimated to have a $5 \%$ increase in within-herd prevalence of KET (Table 3).

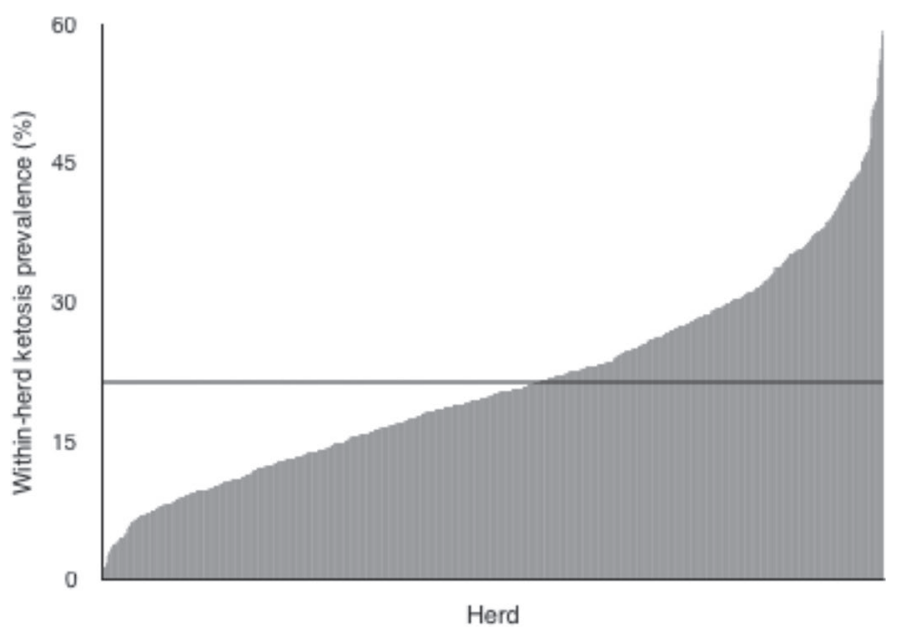

Figure 3. Within-herd prevalence of ketosis based on milk BHB $\geq 0.15 \mathrm{mmol} / \mathrm{L}$ at DHIA first test for 795 herds with $\geq 61$ first tests between June 2014 and December 2015, when first test $\leq 30$ DIM. The mean within-herd prevalence of $21 \%$ for all tested herds is indicated with the horizontal black line. 
Table 2. Herd demographics of all Ontario dairy herds enrolled in a DHIA program collected from June 2014 to December 2015 compared with those herds with $\geq 61$ first test observations over the same period

\begin{tabular}{lcc}
\hline & All herds & $\begin{array}{c}\text { Herds with } \geq 61 \\
\text { test days }\end{array}$ \\
Variable & 3,042 & 795 \\
Number of herds & 165,749 & 89,787 \\
Number of cows & $67.6(50.5)$ & $126.4(98.8)$ \\
Mean (median) number of lactating cows & $54.3(40.5)$ & $112.9(89.0)$ \\
Mean (median) number of first DHIA tests per herd & & \\
Barn type by number (\%) of herds & $868(28)$ & $476(60)$ \\
Free stall & $1,877(62)$ & $236(30)$ \\
Tie stall & $297(10)$ & $83(10)$ \\
Other & $200(7)$ & $91(11)$ \\
Number $(\%)$ of herds with an automated milking system & & $85,461(95)$ \\
Breed number (\%) of cows & $154,597(93)$ & $2,958(3)$ \\
Holstein & $7,546(5)$ & $1,368(2)$ \\
Jersey & $3,606(2)$ & $17.4(\mathrm{SE}=0.03)$ \\
Other & $17.4(\mathrm{SE}=0.03)$ & $9,128(\mathrm{SE}=37)$ \\
Average DIM at first test & $8,759(\mathrm{SE}=22)$ & $245(\mathrm{SE}=1.1)$ \\
Average M305 ${ }^{1}$ (kg) & $233(\mathrm{SE}=0.60)$ & \\
Average F305 ${ }^{2}$ (kg) & & \\
${ }^{1}$ M305 = 305-d milk yield. & & \\
${ }^{2}$ F305 = 305-d fat yield. & &
\end{tabular}

\section{Risk Factors for Ketosis in Primiparous and Multiparous Animals}

Several variables associated with KET at first DHIA milk tests were similar in PP and MTP animals (Tables 4 and 5). Season and DIM at first test were associated with KET in all parities. The highest prevalence of KET for both groups occurred in May and February. The odds of KET at first test were lowest in October, compared with May. The odds of KET remained low from July through November. In both groups, DIM at first test was associated with KET, with the odds of KET at first test decreasing as DIM increased. The odds of KET were 2.57 (95\% CI: 2.41 to 2.73) times greater for PP and 1.45 (95\% CI: 1.39 to 1.50) times greater for MTP animals that had milk sampled in the first 2 wk of lactation compared with those sampled in the fourth week.

Breed was associated with KET at first DHIA test in both parity models. Jerseys had odds of KET 1.46
(95\% CI: 1.23 to 1.73 ) and 1.47 (95\% CI: 1.32 to 1.65 ) times greater than Holsteins, for PP and MTP animals, respectively.

The herd average M305 was associated with the odds of KET in PP and MTP animals, but the direction of the relationship differed. Having a herd average M305 above the median in PP animals decreased the odds of KET by 0.82 ( $95 \%$ CI: 0.73 to 0.94 ) when compared with animals from herds in the lowest quartile for the herd average M305. In MTP animals, having a herd average M305 in the lowest quartile was protective for KET when compared with animals in herds with higher average M305. Multiparous animals from herds with the highest herd average M305 had the highest odds of KET (odds ratio: $1.27 ; 95 \%$ CI: 1.16 to 1.40 ). The ICC at the herd-level for PP animals was $16 \%$, whereas the ICC for MTP animals at the herd level was $10 \%$ based on the null models.

Contrary to the herd average milk production, increased fat yield at the last DHIA test of the previous

Table 3. Final linear regression model of factors associated with the square root of the within-herd prevalence of ketosis (milk BHB $\geq 0.15 \mathrm{mmol} / \mathrm{L}$ ) for 165,749 cows in 795 herds in Ontario with $\geq 61$ DHIA tests within 30 DIM

\begin{tabular}{|c|c|c|c|c|}
\hline Variable & Estimate & $\mathrm{SE}$ & $95 \% \mathrm{CI}$ & $P$-value \\
\hline \multicolumn{5}{|l|}{ Automatic milking system } \\
\hline No & Referent & & & \\
\hline Yes & 0.46 & 0.13 & 0.21 to 0.72 & $<0.001$ \\
\hline \multicolumn{5}{|l|}{ Proportion of tests in summer } \\
\hline$<33 \%$ & Referent & & & \\
\hline$\geq 33 \%$ & -0.25 & 0.08 & -0.42 to -0.09 & $<0.001$ \\
\hline
\end{tabular}


Table 4. Final logistic regression model of factors associated with ketosis (milk BHB $\geq 0.15$ mmol/L) for 55,678 first-parity cows in 2,984 herds in Ontario ${ }^{1}$

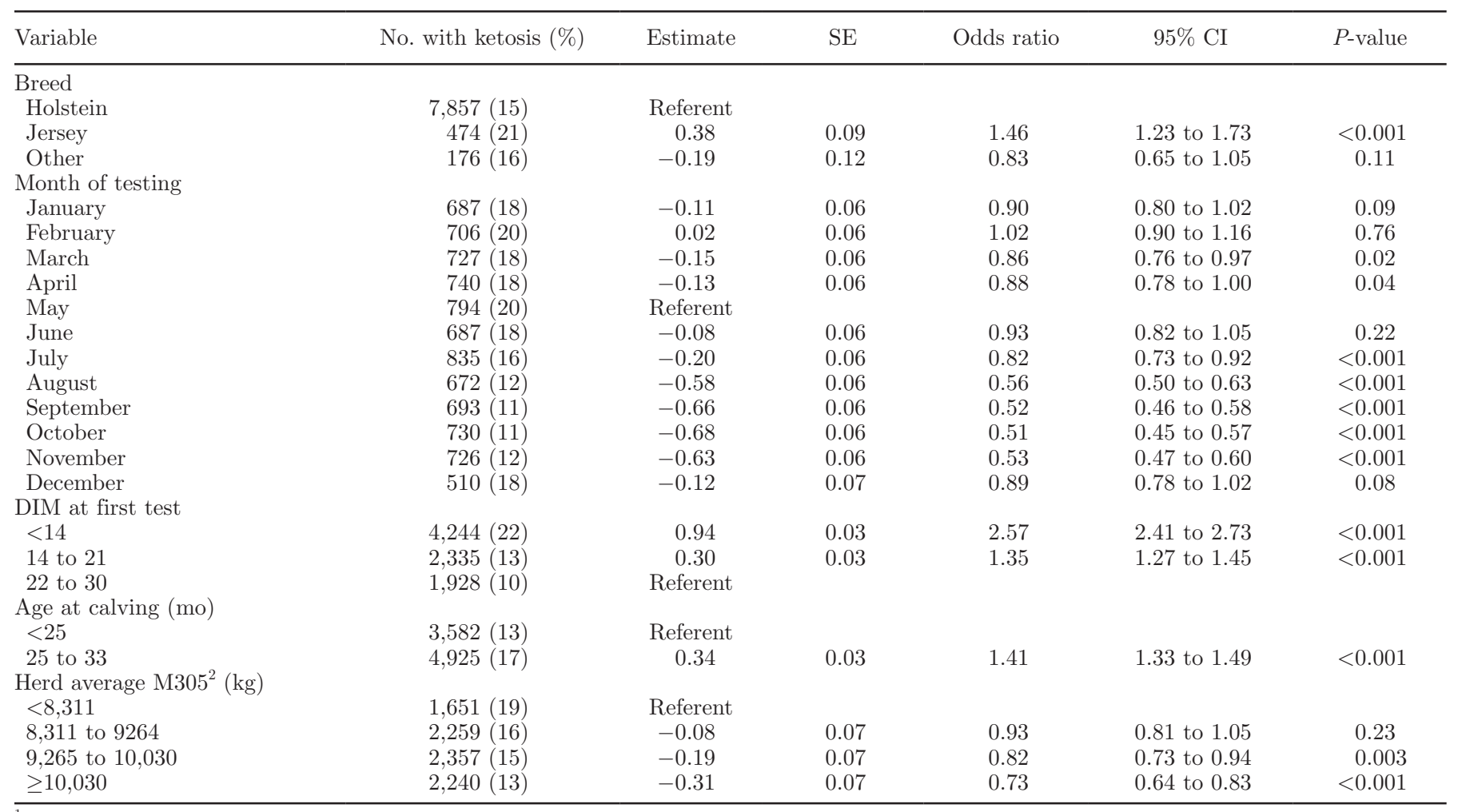

${ }^{1}$ Herd is included as a random effect.

${ }^{2} \mathrm{M} 305=305-\mathrm{d}$ milk yield.

lactation was associated with decreased odds of KET at the first DHIA test of the current lactation for MTP animals (Table 5). For example, animals producing $\geq 1.12 \mathrm{~kg}$ of fat at the last test of the previous lactation had odds of KET of 0.56 (95\% CI: 0.53 to 0.59 ) compared with animals that produced $<0.70 \mathrm{~kg}$ of fat at last test.

The number of days dry was associated with the odds of KET at first test, with the odds of KET increasing with increasing days dry (Table 5). Similarly, when compared with a 12-mo calving interval, a calving interval between 13 and 15 mo was associated with 1.39 times greater odds of KET (95\% CI: 1.33 to 1.46), and if the calving interval was $>15$ mo the odds increased to 1.96 times (95\% CI: 1.87 to 2.05). For PP animals, age at first calving $\geq 25$ mo increased the odds of KET to 1.41 -fold (95\% CI: 1.33 to 1.49$)$ relative to first calving $<25$ mo.

Herd size and barn type were not associated with KET at first test for either parity group; however, having AMS was significantly associated with KET at first test for MTP animals (odds ratio: $1.45 ; \mathrm{CI}_{95 \%}: 1.30$ to 1.62). Being in an AMS herd was not associated with KET for PP animals.

\section{DISCUSSION}

Overall KET prevalence at first DHIA test before 30 DIM was $21 \%$, which is similar to a recent European estimate of $21.8 \%$ based on blood BHB $\geq 1.2 \mathrm{mmol} / \mathrm{L}$ sampled from 2 to 15 DIM (Suthar et al., 2013). Another recent European study conducted in the Netherlands estimated an overall KET prevalence of over $58 \%$ when testing animals 7 to 14 DIM using serum BHB (Vanholder et al., 2015). Berge and Vertenten (2014) also reported a high overall prevalence of KET in Europe of $39 \%$, when using the KetoTest milk strip (Ketolac test strip; Sanwa Kagaku Kenkyusho Co. Ltd., Nagoya, Japan) once between 7 and 21 DIM for diagnosis. The KET prevalence in a previous cross-sectional survey of 92 dairy farms in Ontario in the early 1990s was $20 \%$ (Duffield et al., 1997). Although the majority of the herds at that time were tie-stall and component-fed, the prevalence of KET in the present study was similar.

The average within-herd KET prevalence for dairy herds in Ontario based on first test DHIA milk BHB was $21 \%$. The within-herd prevalence in this study was lower than the within-herd prevalence reported for $\mathrm{Eu}-$ ropean herds (43\%; Berge and Vertenten, 2014). Herds 
in the European study did not use KET monitoring or prevention programs, whereas the herds in the current study may include both those that do and do not have KET prevention strategies in place.

The prevalence of KET was highest in May, with decreased KET prevalence occurring from July to November. We expected to see an increased prevalence during the warmer months of July and August; however, European studies have reported a similar higher prevalence in spring (Suthar et al., 2013; Berge and Vertenten, 2014; Vanholder et al., 2015). Factors that may affect the prevalence of KET seasonally could be related to feed quality, amount of butyrate in feed, or reduced labor spent on fresh cow programs due to more time-sensitive concerns (e.g., planting). More work is required to investigate the reason for seasonality in KET prevalence.

The peak KET prevalence occurred at 6 and 7 DIM and decreased over 30 DIM. This finding is consistent with previous work, indicating a higher prevalence in the first 2 wk of lactation (Duffield et al., 1997; Rasmussen et al., 1999; McArt et al., 2012). Our results

Table 5. Final logistic regression model of factors associated with ketosis (milk BHB $\geq 0.15 \mathrm{mmol} / \mathrm{L}$ ) for 100,509 parity $\geq 2$ cows in 3,015 herds in Ontario ${ }^{1}$

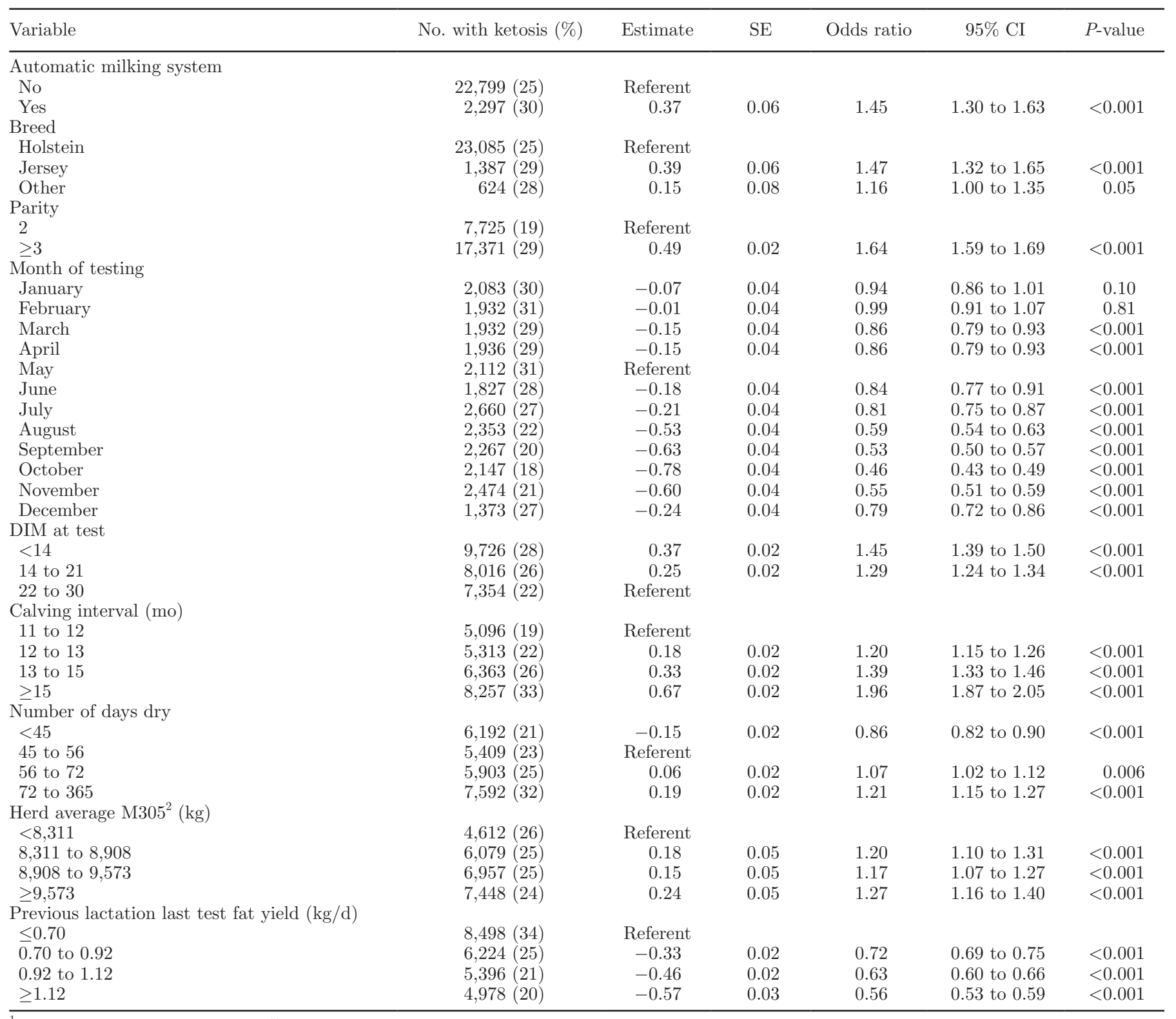

${ }^{1}$ Herd is included as a random effect.

${ }^{2} \mathrm{M} 305=305-\mathrm{d}$ milk yield. 
suggest that KET prevalence peaks 1 to $2 \mathrm{~d}$ later than what was reported by McArt et al. (2012) where KET prevalence peaked at 5 DIM; however, DHIA does not test animals $<5$ DIM and testing protocol may have prevented finding KET at earlier DIM. Primiparous animals peaked at 5 DIM and then dropped quickly. The proportion of PP to MTP animals may change the timing of peak prevalence. The pattern of prevalence of KET for PP and MTP animals was similar to the result described by Santschi et al. (2014). The reason for the difference in peak timing is unclear and warrants further investigation. Whereas older European (Andersson and Emanuelson, 1985) and Canadian (Dohoo and Martin, 1984) studies indicated a peak incidence of KET at 3 to $4 \mathrm{wk}$ in lactation, a later peak in prevalence was not observed in the current population (Dohoo and Martin, 1984; Andersson and Emanuelson, 1985). The difference in timing compared with older studies represents a change in the ability to manage negative energy balance as lactation progresses past the first few weeks.

Jersey cattle had higher odds of KET at first DHIA test compared with Holsteins. A difference in KET prevalence between other breeds has been illustrated in previous literature. Another Canadian prevalence study demonstrated a higher KET prevalence in Jersey and Canadienne cattle than Holsteins (Santschi et al., 2014). Andersson and Emanuelson (1985) reported that Swedish Red and White had higher milk acetone concentrations than Swedish Friesians. A European study (Berge and Vertenten, 2014) found no association between breed and KET prevalence; however, the study cited lack of variation in breed as one reason for the lack of difference between herds. Further work is required to determine the relevance of elevated KET prevalence in breeds other than Holsteins and whether previously determined KET thresholds based on disease risk are consistent across breeds.

In PP animals, age at first calving $\geq 25$ mo increased the odds of KET at first DHIA test, similar to previous work by Gordon (2013) who found that calving greater than 24 mo increased the risk of KET by 1.7 times. Gordon (2013) also reported increased risk of KET with increasing days dry; however, in that study it was categorized into 2 groups, whereas we reported days dry in quartiles and demonstrated not only an increase in the odds of KET when days dry were between 56 and $72 \mathrm{~d}$, but also that the odds of KET were even greater when days dry were $>72 \mathrm{~d}$.

Rasmussen et al. (1999) found that higher previous lactation M305 was associated with higher odds of KET in the current lactation. Gordon (2013) found no association between previous lactation M305 and the risk of KET in early lactation in 4 American dairy herds. Interestingly, previous lactation total milk yield $(\mathrm{kg})$ was significant in the univariable analysis in the current study; however, when accounting for calving interval, the previous lactation total milk yield $(\mathrm{kg})$ was no longer a significant predictor. Having a longer calving interval was associated with higher odds of KET. Fat yield at the last DHIA test of the previous lactation was associated with KET. Multiparous animals with higher fat yield at last test had lower odds of KET at first DHIA test of the current lactation. It is possible that producing more milk fat in later lactation indicates that dietary energy is being partitioned to the milk rather than deposited as adipose tissue (Allen and Piantoni, 2014). Higher body condition prepartum is associated with KET postpartum (Gillund et al., 2001; McArt et al., 2013). We did not have BCS data in this study and further work would be required to confirm this hypothesis and to examine the association between last test fat yield and BCS or body fat composition.

The odds of KET at first DHIA test were increased for PP animals in the lowest quartile for average herd M305. In MTP animals, the association of average herd M305 and KET at first test were in the opposite direction. In PP animals, average herd milk production may be a surrogate measure for management. The PP variation at the herd level was higher than the herdlevel variation of MTP animals, suggesting that with increasing parity, more cow-level factors affect the risk of KET. Average herd milk production may also be affected by the KET prevalence of the herd and may be a situation of reverse causation. A higher prevalence of KET within the herd may decrease the overall herd-average milk production, but also increase an individual's odds of having KET.

Herds with AMS were associated with both higher within-herd KET prevalence and higher odds of KET at first DHIA test for MTP animals. This relationship has not been previously reported. There are several differences between AMS herds and parlor or pipeline milking systems including milking frequency and feeding management. Providing some of the dietary intake through pelleted feed may contribute to KET. Berge and Vertenten (2014) reported herds with a partial mixed ration had the highest KET prevalence at 50\% compared with $33 \%$ for component fed herds and $36 \%$ for TMR-fed herds. Automatic milking system herds allow more frequent milkings, contributing to an increased milk yield (Wagner-Storch and Palmer, 2003; Jacobs and Siegford, 2012); an increase in yield in early lactation may also increase the magnitude of negative energy balance and may increase the odds of KET. Milking system was not associated with KET for PP animals. Much of transition management occurs before 
lactation; PP animals are reared similarly in both AMS and non-AMS herds, reducing the difference between groups in the odds of KET in early lactation.

Limited information is available directly comparing blood BHB and milk BHB results from FTIR analysis. The sensitivity and specificity of FTIR milk BHB compared with blood BHB $\geq 1.2 \mathrm{mmol} / \mathrm{L}$ was 34 and $89 \%$, respectively, when the milk threshold was $\mathrm{BHB} \geq 0.20$ $\mathrm{mmol} / \mathrm{L}$ (Wilson and Goodell, 2013). It is unclear how the sensitivity and specificity would change at the threshold of milk BHB $\geq 0.15 \mathrm{mmol} / \mathrm{L}$, as the sensitivity of milk BHB tests decreases drastically between 0.10 and $0.20 \mathrm{mmol} / \mathrm{L}$ (Tatone et al., 2016). Milk BHB may be more variable due to the mammary utilization of BHB in milk fat (Bergman, 1971), and it is unclear if other factors, such as milk yield or SCC, interfere with BHB measurement. More work is required to understand the dynamics between blood and milk BHB.

One of the main limitations of this work is that the within-herd KET prevalence estimate is based on a small subset $(26 \%)$ of the herds on DHIA in Ontario. The exclusion of herds was based on the number of DHIA tests within the first 30 DIM to provide a reasonably precise estimate of herd-level prevalence. The decision was made to include only herds with 61 tests or more to estimate within-herd prevalence. The herd demographics of the complete set of herds differed compared with those included in the within-herd prevalence calculation (Table 2). The average herd size was much larger in the reduced data set, and the proportion of tie-stall herds was reduced by $50 \%$. However, barn type and herd size were not associated with KET postpartum in any of the models, including the cowlevel models that incorporated all herds in the data set. The lack of association in the cow-level models suggests that it does not have a large effect on the within-herd prevalence estimates.

The frequency of DHIA sampling (every $4-5 \mathrm{wk}$ ) meant that many cows would not be tested within the critical time period of the first $2 \mathrm{wk}$ in lactation, making the test unsuitable as an individual diagnostic test. The effect of the sampling frequency of the DHIA tests on the within-herd prevalence estimate compared with a within-herd prevalence of a more regular onfarm monitoring program will likely underestimate the within-herd prevalence slightly. The effect of the testing scheme is variable depending on the calving pattern and herd size. If calvings were equally distributed across $5 \mathrm{wk}$, then the DHIA testing scheme would test $2 / 5$ of the cows in the critical period. Thirty-nine percent of cows in this data set were tested within the first $2 \mathrm{wk}$ of lactation, and $66 \%$ of cows were tested by 21 DIM. In addition, the reduced frequency of sampling could potentially reduce the sensitivity to detect risk factors for KET or lead to a reduced magnitude of effect for those risk factors identified.

\section{CONCLUSIONS}

The overall prevalence of KET of cows and the average within-herd prevalence on Ontario dairy farms enrolled in a DHIA milk program was $21 \%$. Due to the large number of records available, previously unreported associations with the prevalence of KET could be explored. Barn type and herd size had no association with herd-level prevalence or the cow-level odds of KET on dairy farms in Ontario enrolled in a DHIA program. A marked seasonal effect on KET prevalence and individual risk was present with the lowest KET prevalence occurring from July to November. This is the first report of higher within-herd KET prevalence and increased odds of KET in MTP animals in AMS herds. Future work should investigate the potential mechanism for this increase in KET and indicate areas where management should be adjusted. The decreased odds of KET in MTP animals with high milk fat yield at the final DHIA test of the previous lactation has not been previously documented. Future work should investigate the association between last test milk fat yield and BCS or body fat composition, with the potential to use last test fat yield as an indicator for cows at risk for KET in the next lactation.

\section{ACKNOWLEDGMENTS}

Funding for this project was provided by a grant from the Ontario Ministry Agriculture, Food, and Rural Affairs (Guelph, ON, Canada), the Dairy Farmers of Ontario (Mississauga, ON, Canada), and CanWest DHI (Guelph, ON, Canada). Data analysis and preparation of the manuscript were done independently of the project funders. The authors declare no conflicts of interest.

\section{REFERENCES}

Al-Rawashdeh, O. F. 1999. Prevalence of hyperketonemia and association with herd size, lactation stage, parity, and periparturient diseases in Jordanian dairy cattle. Prev. Vet. Med. 40:117-125.

Allen, M. S., and P. Piantoni. 2014. Carbohydrate Nutrition: Managing energy intake and partitioning through lactation. Vet. Clin. North Am. Food Anim. Pract. 30:577-597.

Andersson, L., and U. Emanuelson. 1985. An epidemiological study of hyperketonaemia in Swedish dairy cows: Determinants and the relation to fertility. Prev. Vet. Med. 3:449-462.

Asl, A. N., S. Nazifi, A. R. Ghasrodashti, and A. Olyaee. 2011. Prevalence of subclinical ketosis in dairy cattle in the Southwestern Iran 
and detection of cutoff point for NEFA and glucose concentrations for diagnosis of subclinical ketosis. Prev. Vet. Med. 100:38-43.

Baldwin, B. R., N. E. Forsberg, and C. Y. Hu. 1985. Potential for altering energy partitioning in the lactating cow. J. Dairy Sci. 68:3394-3402.

Berge, A. C., and G. Vertenten. 2014. A field study to determine the prevalence, dairy herd management systems, and fresh cow clinical conditions associated with ketosis in western European dairy herds. J. Dairy Sci. 97:2145-2154.

Bergman, E. N. 1971. Hyperketonemia-ketogenesis and ketone body metabolism. J. Dairy Sci. 54:936-948.

Canadian Dairy Commission. 2015. Types of Dairy Barns. Accessed Apr. 20, 2016. http://www.cdc-ccl.gc.ca/.

Compton, C. W. R., S. McDougall, L. Young, and M. A. Bryan. 2014 Prevalence of subclinical ketosis in mainly pasture-grazed dairy cows in New Zealand in early lactation. N. Z. Vet. J. 62:30-37.

Dohoo, I. R., and S. W. Martin. 1984. Subclinical ketosis: Prevalence and associations with production and disease. Can. J. Comp. Med. $48: 1-5$.

Dohoo, I. R., S. W. Martin, and H. Stryhn. 2009. Veterinary Epidemiology Research. 2nd ed. Friesians, Manitoba, Canada.

Duffield, T. F., D. F. Kelton, K. E. Leslie, K. D. Lissemore, and J. H. Lumsden. 1997. Use of test-day milk fat and milk protein to detect subclinical ketosis in dairy cattle in Ontario. Can. Vet. J. 38:713-718.

Duffield, T. F., K. D. Lissemore, B. W. McBride, and K. E. Leslie. 2009. Impact of hyperketonemia in early lactation dairy cows on health and production. J. Dairy Sci. 92:571-580.

Foss Analytical. 2009. Application Note 35: MilkoScan FT+ Ketosis Calibrations. 1: 1-10. Foss, Hillerød, Denmark.

Garro, C. J., L. Mian, and M. C. Roldán. 2014. Subclinical ketosis in dairy cows: Prevalence and risk factors in grazing production system. J. Anim. Physiol. Anim. Nutr. (Berl.) 98:838-844.

Geishauser, T., K. E. Leslie, J. Tenhag, and A. Bashiri. 2000. Evaluation of eight cow-side ketone tests in milk for detection of subclinical ketosis in dairy cows. J. Dairy Sci. 83:296-299.

Gillund, P., O. Reksen, Y. T. Gröhn, and K. Karlberg. 2001. Body condition related to ketosis and reproductive performance in Norwegian dairy cows. J. Dairy Sci. 84:1390-1396.

Gordon, J. L. 2013. Risk factors for and treatment of ketosis in lactating dairy cattle. DVSc Thesis. Department of Population Medicine, University of Guelph, Guelph, Canada.
Jacobs, J. A., and J. M. Siegford. 2012. Invited Review: The impact of automatic milking systems on dairy cow management, behavior, health, and welfare. J. Dairy Sci. 95:2227-2247.

McArt, J. A. A., D. V. Nydam, and G. R. Oetzel. 2012. Epidemiology of subclinical ketosis in early lactation dairy cattle. J. Dairy Sci. 95:5056-5066.

McArt, J. A. A., D. V. Nydam, and G. R. Oetzel. 2013. Dry period and parturient predictors of early lactation hyperketonemia in dairy cattle. J. Dairy Sci. 96:198-209.

McArt, J. A. A., D. V. Nydam, and M. W. Overton. 2015. Hyperketonemia in early lactation dairy cattle: A deterministic estimate of component and total cost per case. J. Dairy Sci. 98:2043-2054.

Rasmussen, L. K., B. L. Nielsen, J. E. Pryce, T. T. Mottram, and R. F. Veerkamp. 1999. Risk factors associated with the incidence of ketosis in dairy cows. Anim. Sci. 68:379-386.

Samiei, A., J. B. Liang, G. R. Ghorbani, H. Hirooka, H. Yaakub, and M. Tabatabaei. 2010. An evaluation of beta-hydroxybutyrate in milk and blood for prediction of subclinical ketosis in dairy cows. Pol. J. Vet. Sci. 13:349-356.

Santschi, D. E., R. K. Moore, and D. M. Lefebvre. 2014. Prevalence of subclinical ketosis detected by near infra-red analysis of BHB in DHI milk samples. J. Dairy Sci. 97 (E Suppl.):868 (Abstr.)

Suthar, V. S., J. Canelas-Raposo, A. Deniz, and W. Heuwieser. 2013 Prevalence of subclinical ketosis and relationships with postpartum disease in European dairy cows. J. Dairy Sci. 96:2925-2938.

Tatone, E. H., J. L. Gordon, J. Hubbs, S. J. LeBlanc, T. J. DeVries, and T. F. Duffield. 2016. A systematic review and meta-analysis of the diagnostic accuracy of point-of-care tests for the detection of hyperketonemia in dairy cows. Prev. Vet. Med. 130:18-32.

Vanholder, T., J. Papen, R. Bemers, G. Vertenten, and A. C. B. Berge. 2015. Risk factors for subclinical and clinical ketosis and association with production parameters in dairy cows in the Netherlands. J. Dairy Sci. 98:880-888.

Wagner-Storch, A. M., and R. W. Palmer. 2003. Feeding behavior, milking behavior, and milk yields of cows milked in a parlor versus an automatic milking system. J. Dairy Sci. 86:1494-1502.

Wilson, D. J., and G. M. Goodell. 2013. Comparison of blood strips, milk strips and automated milk measurement of beta-hydroxybutyrate in periparturient dairy cattle and resultant diagnoses of ketosis. J. Vet. Sci. Technol. 4:136-138. https://doi.org/10.4172/21577579.1000136 . 